\title{
Heavy Metal Removal from Aqueous Solution Using Biosurfactants Produced by Pseudomonas aeruginosa with Corn Oil as Substrate
}

\author{
Venty Suryanti ${ }^{1{ }^{*}}$, Sri Hastuti ${ }^{1}$, Tutik Dwi Wahyuningsih ${ }^{2}$, Mudasir $^{2}$, \\ Dian Kresnadipayana ${ }^{1,3}$, and Inge Wiratna ${ }^{1}$ \\ ${ }^{1}$ Department of Chemistry, Faculty of Mathematics and Natural Sciences, Sebelas Maret University, \\ Jl. Ir. Sutami 36A, Surakarta 57126, Indonesia \\ ${ }^{2}$ Department of Chemistry, Faculty of Mathematics and Natural Sciences, Universitas Gadjah Mada, \\ Sekip Utara, Yogyakarta 55281, Indonesia \\ ${ }^{3}$ Faculty of Health Sciences, Setia Budi University, Jl. Letjen Sutoyo, Mojosongo, Surakarta, Indonesia
}

Received October 9, 2017; Accepted February 26, 2018

\begin{abstract}
The batch removal of $\mathrm{Cu}(\mathrm{II}), \mathrm{Cd}(\mathrm{II})$ and $\mathrm{Pb}$ (II) from individual heavy metal ion aqueous synthetic solution using biosurfactants produced by Pseudomonas aeruginosa with corn oil as substrate was investigated. The metal ion removal process of crude preparation biosurfactants (CPB) was established to be dependent on the initial $\mathrm{pH}$ and contact time. The optimum metal removal was observed at $\mathrm{pH} 6.0$ of the initial metal solution and 10 min of contact time. The affinity sequence for metal ion removal was $\mathrm{Pb}(\mathrm{II})>\mathrm{Cd}(\mathrm{II})>\mathrm{Cu}(\mathrm{II})$. The removal capacity value of biosurfactant for $\mathrm{Cu}(\mathrm{II}), \mathrm{Cd}(\mathrm{II})$ and $\mathrm{Pb}(\mathrm{II})$ from single metal ions solution were $0.169,0.276$ and $0.323 \mathrm{mg} / \mathrm{g}$, respectively. The removal capacity value of biosurfactant for $\mathrm{Cu}(\mathrm{II}), \mathrm{Cd}(\mathrm{II})$ and $\mathrm{Pb}$ (II) from multi metal ions solution were $0.064,0.215$ and $0.275 \mathrm{mg} / \mathrm{g}$, respectively. The removal capacity of individual metal ion was diminished by the presence of other metal ions in multi metal ions from synthetic aqueous solution. The removal capacity value of biosurfactant for $\mathrm{Cu}(\mathrm{II}), \mathrm{Cd}(\mathrm{II})$ and $\mathrm{Pb}(\mathrm{II})$ from silver industry wastewater were $0.027,0.055$ and $0.291 \mathrm{mg} / \mathrm{g}$, respectively. The results indicated that biosurfactants have potential to be used in the remediation of heavy metals in industrial wastewater.
\end{abstract}

Keywords: removal capacity; biosurfactants; corn oil; heavy metal; Pseudomonas aeruginosa

\section{ABSTRAK}

Pengambilan ion logam $\mathrm{Cu}(\mathrm{II}), \mathrm{Cd}(\mathrm{II})$ dan $\mathrm{Pb}$ (II) dengan metode batch dari larutan menggunakan biosurfaktan yang diproduksi oleh Pseudomonas aeruginosa menggunakan minyak jagung sebagai substrat telah dipelajari. Proses pengambilan ion logam oleh biosurfaktan yang belum dimurnikan tergantung oleh $\mathrm{pH}$ awal dan waktu kontak. Pengambilan ion logam berat dalam larutan mempunyai kondisi optimum pada $\mathrm{pH}$ awal larutan 6,0 dan waktu kontak 10 menit. Urutan kekuatan pengambilan ion logam berat oleh $\mathrm{CPB}$ adalah $\mathrm{Pb}(\mathrm{II})>\mathrm{Cd}(\mathrm{II})>\mathrm{Cu}(\mathrm{II})$. Biosurfaktan mempunyai kapasitas pengambilan untuk logam $\mathrm{Cu}(\mathrm{II}), \mathrm{Cd}(\mathrm{II})$ dan $\mathrm{Pb}$ (II) dari larutan logam tunggal adalah berturut-turut 0,169; 0,276; and 0,323 mg/g. Biosurfaktan mempunyai kapasitas pengambilan untuk logam $\mathrm{Cu}(\mathrm{II}), \mathrm{Cd}(\mathrm{II})$ dan $\mathrm{Pb}$ (II) dari larutan logam bersaing adalah berturut-turut 0,064; 0,215; and $0.275 \mathrm{mg} / \mathrm{g}$. Kapasitas pengambilan ion logam berat berkurang karena adanya ion logam lain dalam larutan. Pada pengambilan ion logam berat dalam limbah cair pencucian perak diperoleh kapasitas pengambilan untuk $\mathrm{Cu}(\mathrm{II}), \mathrm{Cd}(\mathrm{II})$ dan $\mathrm{Pb}$ (II) berturutturut adalah 0,027; 0,055; dan 0,291 mg/g. Hasil penelitian menunjukkan bahwa biosurfaktan mempunyai potensi untuk digunakan dalam remidiasi logam berat dalam limbah cair industri.

Kata Kunci: kapasitas penyerapan; biosurfaktan; minyak jagung; logam berat; Pseudomonas aeruginosa

\section{INTRODUCTION}

Biosurfactants are amphiphile compounds which consist of hydrophobic and hydrophilic moieties. In comparison to synthetic surfactants, biosurfactants are environmentally friendly since they are less toxic, nonhazardous and biodegradable. Biosurfactants have been applied for agrochemical solubilization, emulsification, and foaming in food processing and phase dispersion for cosmetic and textiles. Biosurfactants also have potential environmental applications for bioremediation, oil spills control, crude oil transferring and oil recovery enhancement [1-3].

* Corresponding author.

Email address : venty@mipa.uns.ac.id

DOI: 10.22146/ijc.28805

Venty Suryanti et al. 
Research has shown an increasing interest in the application of biosurfactants in remediation technologies to clean up of metals $[1,4-5]$. The ability of biosurfactants to form complexes with metals is a key factor in their effectiveness in the reduction of heavy metal contaminated. Biosurfactants of anionic nature can also seize the metal ions using electrostatic interactions [6-9]. Juwarkar et al. have investigated that the removal of heavy metals from the soil by di-rhamnolipid biosurfactants produced by $P$. aeruginosa BS2 was in the sequence of $\mathrm{Cd} \approx \mathrm{Cr}>\mathrm{Pb} \approx \mathrm{Cu}>\mathrm{Ni}$ [10]. Das et al. have studied that biosurfactant produced by marine bacterium could be employed in the treatment of heavy metal containing wastewater because it can chelate heavy metals and develop insoluble precipitation [11].

We have reported that rhamnolipids biosurfactants could be produced by $P$. flourescens using cassava flour wastewater as media. The biosurfactants exhibited critical micelle concentration (CMC) value of $715 \mathrm{mg} / \mathrm{L}$ and lowered the surface tension of the water from $80 \mathrm{mN} / \mathrm{m}$ to $59 \mathrm{mN} / \mathrm{m}$ [12]. We also have found that soybean oil could be used as a carbon source for rhamnolipids biosurfactants by $P$. aeruginosa. The biosurfactants had the CMC of $860 \mathrm{mg} / \mathrm{L}$ and decreased the surface tension of the water from $72 \mathrm{mN} / \mathrm{m}$ to $52 \mathrm{mN} / \mathrm{m}$ [13]. As an extension of this work, we are interested in the production of biosurfactants by $P$. aeruginosa using corn oil as substrate and the use of these biosurfactants in the removal of heavy metals from contaminated aqueous solution. The objective of this research is finding the alternative way for the reduction of heavy metals using non-hazardous and biodegradable materials to minimize human and environmental exposure of toxic heavy metals. Herein, we report the removal of heavy metal ions from synthetic aqueous solution and silver industrial wastewater using biosurfactants produced by $P$. aeruginosa with corn oil as substrate.

\section{EXPERIMENTAL SECTION}

\section{Materials}

An analytical grade of chemicals from E-Merck were used is this research, whereas corn oil from Sunbeam and palm oil from Bimoli. The strain used throughout this work, P. aeruginosa FNCC 0063, was purchased from Pusat Antar Universitas, Universitas Gadjah Mada, Indonesia.

\section{Instrumentation}

Infrared spectra were obtained by a Shimadzu FTIR-8201 PC Spectrometer. Metal ion concentrations were measured by Atomic Absorption Spectroscopy (AAS), Shimadzu AA 6650.

\section{Procedure}

\section{Media used and growth condition}

Nutrient agar media was used to maintain the cultures of bacteria. Biosurfactant production was performed using media composed of nutrient broth (8 $\mathrm{g} / \mathrm{L}), \mathrm{NaCl}(5.0 \mathrm{~g} / \mathrm{L})$ and $10 \%(\mathrm{v} / \mathrm{v})$ corn oil. The cultures were incubated at room temperature on a reciprocal rotary shaker (150 rpm) for 4 days.

\section{Biosurfactants recovery}

Two forms of the biosurfactants were recovered from the culture liquid. Culture liquid of $P$. aeruginosa was centrifuged at $12,000 \mathrm{~g}$ for $20 \mathrm{~min}$ to obtain culture supernatant, namely crude preparation of biosurfactants (CPB). The extraction technique was applied to the culture supernatant with $n$-hexane and subsequently with chloroform. The extract was evaporated to get biosurfactants free of the solvent. This product was named partially purified of biosurfactants (PPB).

\section{Emulsification index (E24) of biosurfactants}

E24 of PPB was established by adding $2 \mathrm{~mL}$ of oil and the same amount of PPB, mixed by a vortex for $2 \mathrm{~min}$, then left to stand for $24 \mathrm{~h}$. The E24 is presented as a percentage of the height of emulsified layer $(\mathrm{mm})$ divided by the total height of the liquid column $(\mathrm{mm})$.

\section{Surface tensions, interfacial tensions and CMC of biosurfactants}

The surface tension and interfacial tensions of the PPB were quantified by the capillary rise method at room temperature. The PPB was dissolved in distilled water, and the surface tension of the water was evaluated in different concentrations of the PPB. The CMC value is the concentration at which micelles began to form. This value was obtained when the rapid change in the surface tension was noticed. The CMC was calculated by plotting the surface tension as a function of PPB concentration.

\section{Emulsion type of biosurfactants}

Conductivity test was used to identify the emulsion type of PPB. A small amount of an electrolyte was added to the emulsions. The emulsion is oil-water type when the conductance increases. Conversely, the emulsion is water-oil type when there are no significant changes in conductance. In this case, $1 \%(\mathrm{w} / \mathrm{w})$ of sodium chloride was added to the emulsion, and the conductivity was measured. 


\section{Emulsification properties of biosurfactants}

The interfacial surface tension and E24 of the PPB using different hydrocarbons were tested. In a screwcapped tube containing $1 \mathrm{~mL}$ of distilled water and $1 \mathrm{~mL}$ of hydrocarbon was added $0.1 \mathrm{mg}$ of PBB. The interfacial tensions of the emulsions with and without the addition of PPB were measured by the capillary rise method at room temperature. The E24 of the formed emulsions was monitored for 10 days.

\section{Preparation of metal solutions}

The protocol of samples was made by dissolving specified weight of metal nitric salts (copper $\left(\mathrm{Cu}\left(\mathrm{NO}_{3}\right)_{2} .3 \mathrm{H}_{2} \mathrm{O}\right.$, cadmium $\left(\mathrm{Cd}\left(\mathrm{NO}_{3}\right)_{2} .4 \mathrm{H}_{2} \mathrm{O}\right)$ or lead $\left(\mathrm{Pb}\left(\mathrm{NO}_{3}\right)_{2}\right)$ in $1 \mathrm{~L}$ of $0.1 \mathrm{M} \mathrm{HNO}_{3}$ to produce a single metal solution (1000 ppm). A mixture metal solution of concentration of 1000 ppm was formulated by dissolving appropriates amount of $\mathrm{Cu}\left(\mathrm{NO}_{3}\right)_{2} .3 \mathrm{H}_{2} \mathrm{O}, \mathrm{Cd}\left(\mathrm{NO}_{3}\right)_{2} .4 \mathrm{H}_{2} \mathrm{O}$ and $\mathrm{Pb}\left(\mathrm{NO}_{3}\right)_{2}$ in $1 \mathrm{~L}$ of $0.1 \mathrm{M} \mathrm{HNO}_{3}$. The desired $\mathrm{pH}$ metal solutions were modified using $0.1 \mathrm{M} \mathrm{NaOH}$ or $0.1 \mathrm{M} \mathrm{HCl}$ before the biosurfactant was added.

\section{Experimental design}

Batch technique was performed in these experiments. Eight milliliters of 2.5 ppm heavy metal solution or silver industrial wastewater was mixed with CPB (10 ppm) or PPB (10 ppm) in a flask and stirred with $\mathrm{pH}$ adjustment using $0.1 \mathrm{M} \mathrm{NaOH}$ or $0.1 \mathrm{M} \mathrm{HCl}$. The samples were kept at room temperature in a shaker at $150 \mathrm{rpm}$ for definite periods of time. The solution was then filtered through Whatman filter paper No. 42. Residual metal ion concentrations were measured by Atomic Absorption Spectroscopy (AAS) in the filtered samples. The average value of the triplicate experiments was exhibited as a percentage of metal removed.

\section{Calculation} eq. 1.

$$
\mathrm{q}_{\mathrm{e}}=\frac{\left(\mathrm{C}_{\mathrm{i}}-\mathrm{C}_{\mathrm{f}}\right) \times \mathrm{V}}{\mathrm{m}}
$$

where $\mathrm{q}_{\mathrm{e}}$ is the amount of adsorbed ions per mass unit of sorbents $(\mathrm{mg} / \mathrm{g}), \mathrm{C}_{\mathrm{i}}$ is the metal ions initial concentration $(\mathrm{mg} / \mathrm{L})$ and $C_{f}$ is the metal ions final concentration (after treatment with PPB or CPB) $(\mathrm{mg} / \mathrm{L}), \mathrm{V}$ is the aqueous phase volume $(\mathrm{L})$ and $\mathrm{m}$ is the amount of the CPB or PPB used (g).

\section{Analysis}

The results were analyzed statistically, and oneway analysis of variance (ANOVA) was used to examine the differences between groups. Fisher's pairwise comparisons were used to carry out for posttest via statistical package Minitab TM 13 windows. Statistically significant differences were appointed at $\mathrm{p}<0.05$

\section{RESULT AND DISCUSSION}

\section{Production and Characterization of Biosurfactants}

Biosurfactant production was performed using media containing $10 \%(\mathrm{v} / \mathrm{v})$ of corn oil which was incubated for 4 days. The obtained peaks of PPB are similar to those commonly found in the FT-IR spectra of the rhamnolipids biosurfactants. The amphiphilic surface-active glycolipids usually are produced by Pseudomonas spp [14]. Fig. 1 presents the FT-IR spectra of PPB. The strong and broad band at $3417 \mathrm{~cm}^{-1}$ might be related to the $\mathrm{O}-\mathrm{H}$ stretching vibration. The $-\mathrm{CH}$ stretch was confirmed by the band at $2854 \mathrm{~cm}^{-1}$, and the asymmetric stretching vibration of $\mathrm{C}=\mathrm{O}$ was identified by the band at $1643 \mathrm{~cm}^{-1}$. The appearance of $\mathrm{O}-\mathrm{H}$ stretching absorption at $2923 \mathrm{~cm}^{-1}$ and $\mathrm{C}=\mathrm{O}$ stretching at $1724 \mathrm{~cm}^{-1}$, confirming the presence of carboxylic acid groups. The weak band at 1458 and $1377 \mathrm{~cm}^{-1}$ are in the absorption range of $1370-1470 \mathrm{~cm}^{-1}$ resulting from deformation and bending

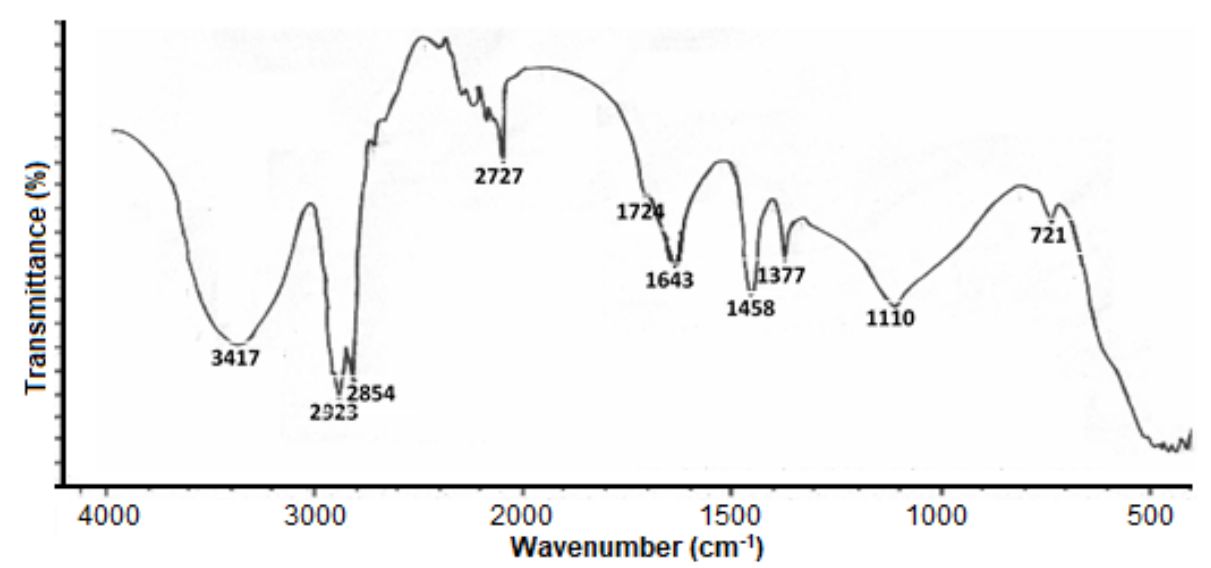

Fig 1. FT-IR spectrum of PPB 
vibrations of aliphatic chains $\left(-\mathrm{CH}_{3}-\right.$ and $\left.\mathrm{CH}_{2}-\right)$. These peaks reflect the presence of alkyl chains in the compounds. The stretching of $\mathrm{C}-\mathrm{O}$ group was found by the presence of the intense and strong band at $1110 \mathrm{~cm}^{-1}$. FT-IR analysis showed that biosurfactants possess $-\mathrm{OH}$ and $-\mathrm{COOH}$ functional groups which could contribute to binding sites in removing toxic pollutants especially metals from the environment. These functional groups can attract and bind metal ion coordinately, thus form a stable complex resulting sorption of the metals.

These biosurfactants exhibited the CMC value of $985 \mathrm{mg} / \mathrm{L}$ and the surface tension value of $70 \mathrm{mN} / \mathrm{m}$. The emulsion type of the biosurfactants is oil in water (o/w). The biosurfactant was able to decrease the interfacial tension by about $30 \%$ when palm oil and kerosene were used as water-immiscible compounds. The biosurfactant formed stable emulsion until 4 days when toluene, benzene, and kerosene were used as water-immiscible compounds and 8 days when palm oil was used as a water-immiscible compound.

\section{Heavy Metal Removal from Single Metal Synthetic Solutions}

Initially, a study was performed to investigate the removal ability of two forms of the biosurfactants. A crude preparation of biosurfactant (CPB) $(10 \mathrm{ppm})$ and partially purified of biosurfactant (PPB) (10 ppm) was applied for removing of $\mathrm{Pb}$ (II) from aqueous solutions. It was observed that the $\mathrm{Pb}$ (II) absorption ability of $\mathrm{CPB}$ and PPB at $\mathrm{pH} 6$ and contact time 10 min were 0.316 and $0.044 \mathrm{mg} / \mathrm{g}$, respectively. The results demonstrated that the CPB significantly has a much better absorption ability of $\mathrm{Pb}$ (II) removals than that of the PPB. This may be as a result of a decrease in the number of biosurfactants functional groups which are responsible for binding of the $\mathrm{Pb}$ (II) due to purification. The functional

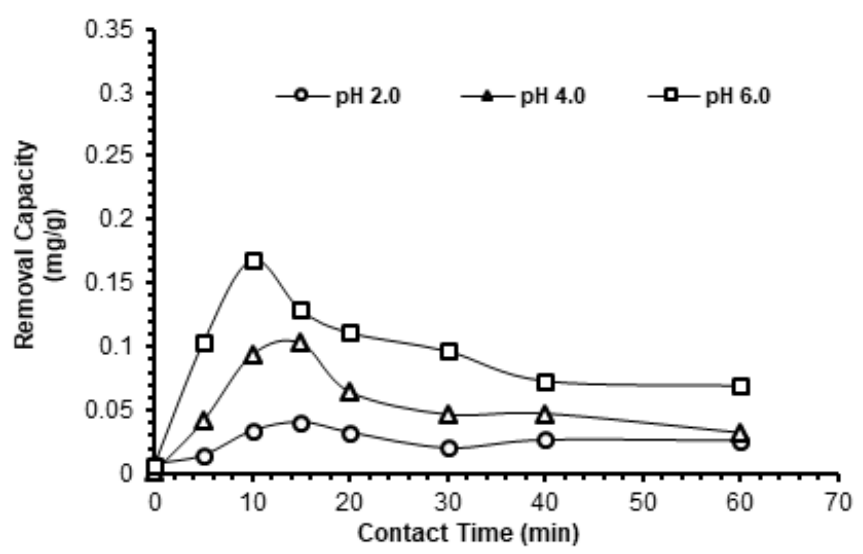

Fig 2. Effect of initial $\mathrm{pH}$ and contact time in the removal capacity of $\mathrm{CPB}$ for the removal of $\mathrm{Cu}(\mathrm{II})$ ion groups (amido, hydroxyl, $\mathrm{C}=\mathrm{O}$, and $\mathrm{C}-\mathrm{O}$ ) have been reported to be involved in the biosorption of $\mathrm{Pb}$ (II) on the surface of $A$. spherical [15]. As the binding site decreased, the amount of $\mathrm{Pb}$ (II) removed by biosurfactant decreased, following the decrease in the removal capacity. Therefore, all subsequent metal ions removal experiments were examined for the CPB.

A set of experiments was conducted to assess the effects of $\mathrm{pH}$ and time of contact on the removal of $\mathrm{Cu}(\mathrm{II}), \mathrm{Cd}(\mathrm{II})$ and $\mathrm{Pb}(\mathrm{II})$ ions from the single metal aqueous solutions by CPB. The $\mathrm{pH}$ solution can cause changes in the ionic state of the metals and the surface charge of biosurfactants. As a consequent, the $\mathrm{pH}$ effects the removal of metal ions from aqueous solutions [16-18]. Since problems with precipitation of tested heavy metals were found to occur at $\mathrm{pH}$ above 6.0 , a series of removal experiments were carried out at initial $\mathrm{pH}$ of 2.0, 4.0, and 6.0 to determine the influence of $\mathrm{pH}$ on removal. At $\mathrm{pH}$ below 2.0, the high proton concentration reduces the metal sorption, whereas, at $\mathrm{pH}$ above 6.0 , the metal hydrate may be developed instead of complexation with CPB. Hence the removal process is difficult to accomplish.

Fig. 2-4 illustrated the effect of initial $\mathrm{pH}$ on the removal of $\mathrm{Cu}(\mathrm{II}), \mathrm{Cd}(\mathrm{II})$ and $\mathrm{Pb}$ (II) ions by CPB. The number of metal ions adsorbed enhanced with an increase in $\mathrm{pH}$. Significantly high removal capacity took place at the initial of $\mathrm{pH} 6.0$, while low removal capacity took place at an initial pH of 2.0 and 4.0. Almost no removal was noticed at $\mathrm{pH}$ 2.0. These findings demonstrated that the presence of excess hydrogen ions at lower $\mathrm{pH}$ competed with the metal ions in the solutions and filled the existing binding sites in CPB. Moreover, at low $\mathrm{pH}$, the metal binding sites became positively charged with repelling the $\mathrm{Cu}(\mathrm{II}), \mathrm{Cd}(\mathrm{II})$ and $\mathrm{Pb}$ (II) cations. The number of hydrogen ions decreases as the $\mathrm{pH}$ of the solution rises, hence causing the removal process more favorable [19-20]. Furthermore,

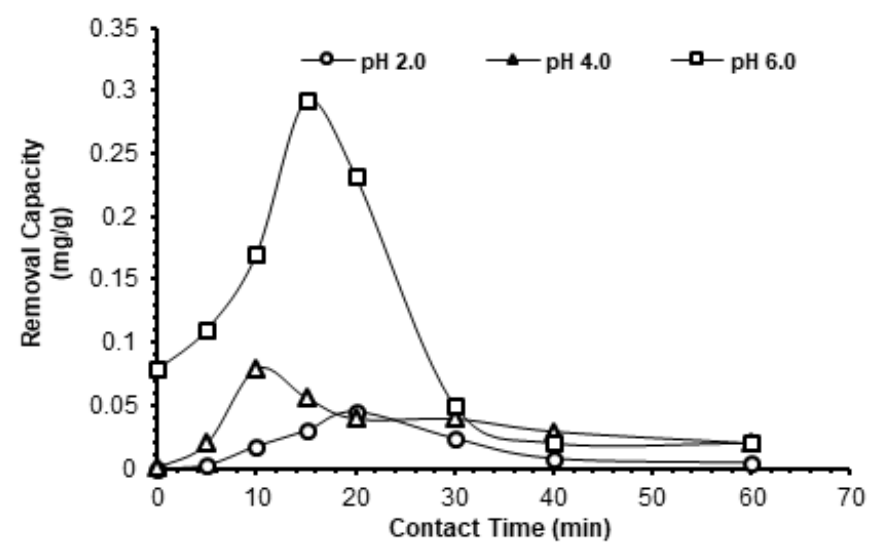

Fig 3. Effect of initial $\mathrm{pH}$ and contact time in the removal capacity of CPB for the removal of $\mathrm{Cd}(\mathrm{II})$ ion 


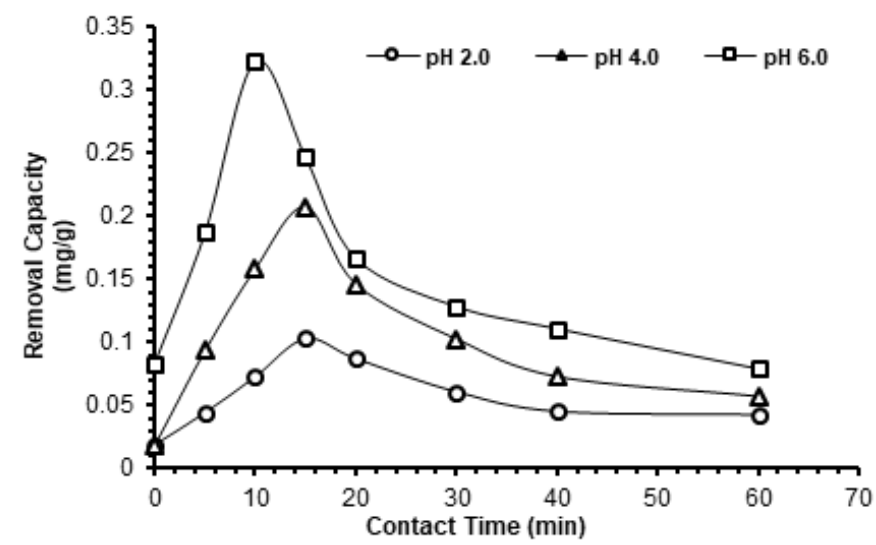

Fig 4. Effect of initial $\mathrm{pH}$ and contact time in the removal capacity of $\mathrm{CPB}$ for the removal of $\mathrm{Pb}$ (II) ion

Table 1. Competition among metal ions for time contact of 10 and $15 \mathrm{~min}$

\begin{tabular}{cccc}
\hline Contact time & \multicolumn{3}{c}{ Removal capacity $(\mathrm{mg} / \mathrm{g})$} \\
\cline { 2 - 4 }$(\mathrm{min})$ & $\mathrm{Cu}(\mathrm{II})$ & $\mathrm{Cd}(\mathrm{II})$ & $\mathrm{Pb}(\mathrm{II})$ \\
\hline 10 & 0.064 & 0.215 & 0.275 \\
15 & 0.061 & 0.165 & 0.221 \\
\hline
\end{tabular}

Table 2. Removal capacity comparison at $\mathrm{pH} 6.0$ with time contact of 10 min for single metal, mixed metal ions solution and silver industrial wastewater

\begin{tabular}{lccc}
\hline \multirow{2}{*}{ Solution } & \multicolumn{3}{c}{ Removal capacity $(\mathrm{mg} / \mathrm{g})$} \\
\cline { 2 - 4 } & $\mathrm{Cu}(\mathrm{II})$ & $\mathrm{Cd}(\mathrm{II})$ & $\mathrm{Pb}(\mathrm{II})$ \\
\hline Single metal & 0.169 & 0.276 & 0.323 \\
Mixed metal ions & 0.064 & 0.215 & 0.275 \\
Silver industrial wastewater & 0.027 & 0.055 & 0.291 \\
\hline
\end{tabular}

the negative charge density of the biosurfactants increases with an increase in $\mathrm{pH}$, due to the deprotonation of the metal binding sites, which leads increasing to heavy metal ion removal. For all subsequent experiments in this study, the $\mathrm{pH}$ of 6.0 was elected since optimum removal was noted and metal precipitation related to higher $\mathrm{pH}$ values could be prevented.

The removal capacities of metal ion were calculated as a function of time to determine an applicable contact time between the CPB and heavy metal ions. Removal experiments were examined with a varying contact time of $0,5,10,15,20,30,40$, and 60 min. As shown in Fig. 2-4, the removal of metal ions by CPB was rapidly increased in first 10 min for $\mathrm{Cu}$ (II) and $\mathrm{Pb}$ (II) ions, and $15 \mathrm{~min}$ for $\mathrm{Cd}(\mathrm{II})$ ion. Conversely, further increase of contact time resulted in a decrease in the removal of heavy metal ions. The initial rapid stage is possibly because of the availability of more binding sites of CPB at the beginning stage of the removal [21-22]. This fast removal at initial phase was possibly due to the initial metal concentration in solution ascent with the number of binding sites available in biosurfactants. The decrease in removal capacities with further increase in contact time may be as a result of the saturation of the binding sites of CPB with metal ions succeeded by the following removal and desorption processes, and in this case, the desorption process is more predominant over the removal [21,23]. Batch experiments for the competitive metal ions were then carried out at $\mathrm{pH} 6.0$ for two different contact times, e.g., 10 and $15 \mathrm{~min}$.

\section{Competition among Metal lons}

As metals studied are frequently discovered with some other metals in wastewaters, a series of experiment was performed to examine the binding of each metal ion in the presence of other metal ions. In the mixture metal ions solution, as presented in Table 1 , the removal capacities of the metal ions with $10 \mathrm{~min}$ of contact time CPB were $0.064 \mathrm{mg} / \mathrm{g}$ for $\mathrm{Cu}(\mathrm{II}), 0.0215$ $\mathrm{mg} / \mathrm{g}$ for $\mathrm{Cd}(\mathrm{II})$ and $0.275 \mathrm{mg} / \mathrm{g}$ for $\mathrm{Pb}(\mathrm{II})$. The removal capacities of $\mathrm{Cu}(\mathrm{II}), \mathrm{Cd}(\mathrm{II})$ and $\mathrm{Pb}$ (II) from a mixture of the metals ions with 15 min of time contact were found to be $0.061,0.165$ and $0.221 \mathrm{mg} / \mathrm{g}$, respectively. The results exhibited that the removal capacity with $10 \mathrm{~min}$ of contact time was significantly higher than that of with 15 min of contact time. Thus, the removal of metal ions for the silver industrial wastewater was conducted at $\mathrm{pH} 6.0$ with $10 \mathrm{~min}$ of contact time.

As presented in Table 2, it was noted that the removal capacities of multi metal ions solution are considerably lower than those of the single metal ion solution. Less availability of binding sites may be the reason why the removal capacity of the multi metal ions solution is lower than that of the single metal ion solution [24-25]. Binding sites present in CBP are competitively distributed among the different metal ions present in the mixed metal ions solution.

At silver industrial wastewater, the removal capacities of $\mathrm{Cu}(\mathrm{II}), \mathrm{Cd}(\mathrm{II})$ and $\mathrm{Pb}(\mathrm{II})$ with $10 \mathrm{~min}$ of time contact were noted to be $0.027,0.055$ and 0.291 $\mathrm{mg} / \mathrm{g}$, respectively. It is noticed that the removal capacity of silver industrial wastewater is considerably lower than those of the mixed metal ions solution possibly because of the presence of other metal ions of interest in silver industrial wastewater. Metal ions usually compete with one another for the binding sites, excluding the binding of $\mathrm{Pb}(\mathrm{II})$ which are relatively unchanged by other metals [26-27].

It was demonstrated that the metal ion removal capacities in three kinds of solutions are the sequence of $\mathrm{Pb}(\mathrm{II})>\mathrm{Cd}(\mathrm{II})>\mathrm{Cu}(\mathrm{II})$. There are some aspects which are affected the sorbent sorption capacity for metal ions from aqueous solution, e.g., the differences in ionic size, the affinity of metal ions for sorbent active group, electronegativity, nature of metal ion salt and atomic weight [28]. Commonly, the metal ion with larger ionic radius will compete slower for active groups than 
those of smaller ionic radius [29]. However, the binding site present in CPB (adsorbents) has a bad affinity for metals with smaller ionic radii. In this study, the typical binding affinities of the CPB for the metals studied are $\mathrm{Cu}(\mathrm{II})<\mathrm{Cd}(\mathrm{II})<\mathrm{Pb}$ (II), while the ionic radii of $\mathrm{Pb}$ (II), $\mathrm{Cd}$ (II) and $\mathrm{Cu}(\mathrm{II})$ are $1.22,0.97$, and $0.72 \AA$, respectively. The electronegativity designates the tendency of an atom to attract electrons, and the electronegativity sequence is $\mathrm{Pb}(2.33)>\mathrm{Cu}(1.90)>\mathrm{Cd}$ (1.69). Overall, the affinity sequences for the three metals tested did not correlate with the ionic radii and electronegativity of the metals. This trend in the greater ionic size, the greater its affinity was also observed by Babatunde et al. for the removal of $\mathrm{Cu}(\mathrm{II})$ and $\mathrm{Zn}$ (II) (ionic radius of $\mathrm{Zn}(\mathrm{II})$ is $0.74 \AA$ ) from aqueous solutions by bamboo root biomass, wherein the sequence of metal ion uptake was $\mathrm{Zn}^{2+}>\mathrm{Cu}^{2+}$ ions [28]. Similarly, Yasemin and Zeki reported that the sequence of the sawdust of walnut is $\mathrm{Pb}(\mathrm{II}) \cong \mathrm{Cd}(\mathrm{II})>\mathrm{Ni}$ (II) (ionic radius of $\mathrm{Ni}(\mathrm{II})$ is $0.69 \AA$ ) [27].

\section{CONCLUSION}

The rhamnolipids type biosurfactant produced by $P$. aeruginosa with corn oil as the substrate can be utilized for the removal of $\mathrm{Cu}(\mathrm{II}), \mathrm{Cd}(\mathrm{II})$ and $\mathrm{Pb}$ (II) from the aqueous solution by batch removal method. The removal process was obtained to be dependent on the initial $\mathrm{pH}$ and contact time. The affinity sequence of the adsorbent was $\mathrm{Pb}(\mathrm{II})>\mathrm{Cd}(\mathrm{II})>\mathrm{Cu}(\mathrm{II})$.

In single metal ions solutions, optimum removal of $\mathrm{Cu}$ (II) and $\mathrm{Pb}$ (II) ions by $\mathrm{CPB}$ was achieved at $\mathrm{pH}$ of 6.0 and contact time of $10 \mathrm{~min}$ with removal capacities of $0.169 \mathrm{mg} / \mathrm{g}$ and $0.323 \mathrm{mg} / \mathrm{g}$, respectively. Optimum removal of $\mathrm{Cd}(\mathrm{II})$ ion was obtained at a $\mathrm{pH}$ of 6.0 and contact time of 15 min with removal capacity of 0.276 $\mathrm{mg} / \mathrm{g}$. For mixture metal ions solutions, the removal capacities of the metal ions at $\mathrm{pH} 6.0$ with $10 \mathrm{~min}$ of contact time on CPB were found to be $0.064,0.0215$ and $0.275 \mathrm{mg} / \mathrm{g}$ for $\mathrm{Cu}(\mathrm{II}), \mathrm{Cd}(\mathrm{II})$ and $\mathrm{Pb}(\mathrm{II})$, respectively. The presence of other metal ions in the aqueous solutions decreased the removal capacity for $\mathrm{Cu}(\mathrm{II}), \mathrm{Cd}(\mathrm{II})$ or $\mathrm{Pb}(\mathrm{II})$. In silver industrial wastewater, the removal capacity of $\mathrm{Cu}(\mathrm{II}), \mathrm{Cd}(\mathrm{II})$ and $\mathrm{Pb}$ (II) on $\mathrm{CPB}$ with $10 \mathrm{~min}$ of time contacts were established to be $0.027,0.055$ and $0.291 \mathrm{mg} / \mathrm{g}$, respectively. The removal capacity of 0.027 , 0.055 and $0.291 \mathrm{mg} / \mathrm{g}$ for $\mathrm{Cu}(\mathrm{II}), \mathrm{Cd}(\mathrm{II})$ and $\mathrm{Pb}(\mathrm{II})$, respectively, were established for silver industrial wastewater with $10 \mathrm{~min}$ of time contact.

\section{ACKNOWLEDGEMENT}

The authors acknowledge their gratitude to Ministry of Research, Technology and Higher Education, Indonesia for the financial support to this research.

\section{REFERENCES}

[1] Pacwa-Płociniczak, M., Płaza, G.A., PiotrowskaSeget, Z., and Cameotra S.S., 2011, Environmental applications of biosurfactants: Recent advances, Int. J. Mol. Sci., 12 (1), 633654.

[2] Banat, I.M., Satpute, S.K., Cameotra, S.S., Patil, R., and Nyayanit, N.V., 2014, Cost effective technologies and renewable substrates for biosurfactants production, Front. Microbiol., 5, 697.

[3] Suryanti, V., Marliyana, S.D., and Wulandari A., 2015, Biosurfactant production by Pseudomonas fluorescens growing on molasses and its application in phenol degradation, AIP Conf. Proc., 1699 (1), 040003.

[4] Suryanti, V., Hastuti, S., and Andriani, D., 2016, Optimization of biosurfactant production in soybean oil by Rhodococcus rhodochrous and its utilization in remediation of cadmium-contaminated solution, IOP Conf. Ser. Mater. Sci. Eng., 107 (1), 012018.

[5] Suryanti, V., Hastuti, S and Pujiastuti, D., 2016, Evaluation of biosurfactants grown in corn oil by Rhodococcus rhodochrous on removing of heavy metal ion from aqueous solution, AIP Conf. Proc., 1710, 030016.

[6] Açıkel, Y.S., 2011, "Use of Biosurfactants in the removal of Heavy Metal lons from Soils" In Biomanagement of Metal-Contaminated Soils, Khan M., Zaidi A., Goel R., and Musarrat J., Eds., Springer, Dordrecht, 183-223.

[7] Aşçı, Y., Nurbaş, M., and Sağ Açıkel, Y., 2010, Investigation of sorption/desorption equilibria of heavy metal ions on/from quartz using rhamnolipid biosurfactant, J. Environ. Manage., 91 (3), 724731.

[8] Juwarkar, A.A., Nair, A., Dubey, K.V., Singh, S.K., and Devotta, S., 2007, Biosurfactant technology for remediation of cadmium and lead contaminated soils, Chemosphere, 68 (10), 1996-2002.

[9] Özdemir, G., and Yapar, S., 2009, Adsorption and desorption behavior of copper ions on $\mathrm{Na}$ montmorillonite: effect of rhamnolipids and $\mathrm{pH}, J$. Hazard. Mater., 166 (2-3), 1307-1313.

[10] Juwarkar, A.A., Dubey, K.V., Nair, A., and Singh, S.K., 2008, Bioremediation of multi-metal contaminated soil using biosurfactant-a novel approach, Indian J. Microbiol., 48 (1), 142-146.

[11] Das, P., Mukherjee, S., and Sen, R., 2009, Biosurfactant of marine origin exhibiting heavy metal remediation properties, Bioresour. Technol., 100 (2), 4887-4890.

[12] Suryanti, V., Marliyana, S.D., Handayani, D.S., and Ratnaningrum, D., 2013, Production and 
characterization of biosurfactant by Pseudomonas fluorescens using cassava flour wastewater as media, Indones. J. Chem., 13 (3), 229-235.

[13] Suryanti, V., Hastuti, S., Wahyuningsih, T.D., Mudasir, and Muliawati, D.I., 2009, Biosurfactants production by Pseudomonas aeruginosa using soybean oil as substrate, Indones. J. Chem., 9 (1), 107-112.

[14] El-Sheshtawy, H.S., and Doheim, M.M., 2014, Selection of Pseudomonas aeruginosa for biosurfactant production and studies of its antimicrobial activity, Egypt. J. Pet., 23 (1), 1-6.

[15] Abdel-Aty, A.M., Ammar, N.S., Ghafar, H.H.A., and Ali, R.K., 2013, Biosorption of cadmium and lead from aqueous solution by fresh water alga Anabaena sphaerica biomass, J. Adv. Res., 4 (4), 367-374.

[16] Abdel-Ghani, N.T., El-Chaghaby, G.A., and Helal, F.S., 2015, Individual and competitive adsorption of phenol and nickel onto multiwalled carbon nanotubes, J. Adv. Res., 6 (3), 405-415.

[17] Salam, O.E.A., Reiad, N.A., and El-Shafei, M.M., 2011, A study of the removal characteristics of heavy metals from wastewater by low-cost adsorbents, J. Adv. Res., 2 (4), 297-303.

[18] Bohli, T., Ouederni, A., Fiol, N., and Villaescusa, I., 2012, Uptake of $\mathrm{Cd}^{2+}$ and $\mathrm{Ni}^{2+}$ metal ions from aqueous solutions by activated carbons derived from waste olive stones, IJCEA, 3 (4), 232-236.

[19] Patil, S., Deshmukh, V., Renukdas, S., and Patel, N., 2011, Kinetics of adsorption of crystal violet from aqueous solutions using different natural materials, Int. J. Environ. Sci., 1 (6), 1116-1134.

[20] Farghali, A.A., Bahgat, M., Allah, A.E., and Khedr, M.H., 2013, Adsorption of $\mathrm{Pb}(\mathrm{II})$ ions from aqueous solutions using copper oxide nanostructures, BeniSuef Univ. J. Basic Appl. Sci., 2 (2), 61-71.

[21] Dawodu, F.A., and Akpomie, K.G., 2014, Simultaneous adsorption of $\mathrm{Ni}(\mathrm{II})$ and $\mathrm{Mn}(\mathrm{II})$ ions from aqueous solution unto a Nigerian kaolinite clay, J. Mater. Res. Technol., 3 (2), 129-141.

[22] Al-Homaidan, A.A., Al-Houri, H.J., Al-Hazzani, A.A., Elgaaly, G., and Moubayed, N.M.S., 2014, Biosorption of copper ions from aqueous solutions by Spirulina platensis biomass, Arabian J. Chem., 7 (1), 57-62.

[23] Argun, M.E., Dursun, S., Ozdemir, C., and Karatas, M., 2007, Heavy metal adsorption by modified oak sawdust: Thermodynamics and kinetics, J. Hazard. Mater., 141 (1), 77-85.

[24] Horsfall, M.J., Abia, A.A., and Spiff, A.I., 2003, Removal of $\mathrm{Cu}(\mathrm{II})$ and $\mathrm{Zn}$ (II) ions from wastewater by cassava (Manihot esculenta Cranz) waste biomass, Afr. J. Biotechnol., 2 (10), 360-364.

[25] El-Kholy, N.G., Badawy, N.A., El-Said, A.G., and Abd El Pasir, A., 2013, Competitive adsorption of $\mathrm{Co}$ (II) in a binary and tertiary system with metal ions $\mathrm{Cr}(\mathrm{III})$ and $\mathrm{Ni}(\mathrm{II})$ on Lewatite S-100 cation exchange resin, Nat. Sci., 11 (3), 41-48.

[26] Gloaguen, V., and Morvan, H., 1997, Removal of heavy metal ions from aqueous solution by modified barks, J. Environ. Sci. Health. Part $A$ Toxic/Hazard. Subst. Environ. Eng., 32 (4), 901912.

[27] Bulut, Y., and Tez, Z., 2007, Removal of heavy metals from aqueous solution by sawdust adsorption, J. Environ. Sci., 19 (2), 160-166.

[28] Babatunde, A.I., Abiola, O.K., Osideko, O.A., and Oyelola, O.T., 2009, Kinetic and equilibrium studies on the adsorption of $\mathrm{Cu}^{2+}$ and $\mathrm{Zn}^{2+}$ ions from aqueous solutions by bamboo root biomass, Afr. J. Biotechnol., 8 (14), 3364-3368.

[29] Ho, Y.S., Wase, D.A.J., and Forster, C.F., 1995, Batch nickel removal from aqueous solution by sphagnum moss peat, Water Res., 29 (5), 1327133. 